\title{
Women's stories implying aspects of anti-Judaism with Christological depiction in Matthew
}

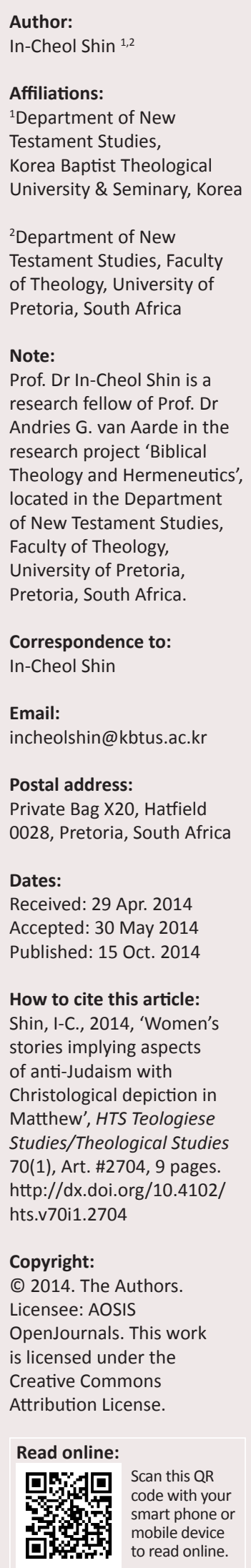

This study focuses on the women's stories that imply aspects of anti-Judaism within Matthew's depiction of Christology, which is called Matthew's theology. In fact, Matthew's community opposed the Jewish system and Jewish leaders and parted from its parent body. Even though Matthew's community was still similar to the Jewish system, it had significant differences as well. The study discusses these aspects of anti-Judaism that appear in the woman's stories that include the genealogy of Jesus, the haemorrhaging woman, the Canaanite woman, and the women at the cross and Jesus' tomb. This study shows proof and examples of anti-Judaism within the stories and thoroughly analyses them. Therefore, it can be confirmed that the women's stories imply aspects of anti-Judaism with Christological depictions by Matthew's theological tendency.

\section{Introduction}

Matthew's narrative has many different stories and discourses. The narrative also includes the women's stories within Jesus' religious movement. It shows us that women's stories are important and should be considered by Matthean scholars. Several considerations have emerged from this research. Firstly, feminist theologians made an effort to understand the various roles of women in the Gospel of Matthew. They have focused on analysing Matthew's narrative through a feminist interpretation rather than from the perspective of androcentric literary tradition (Abel 1981:179-184; Anderson 1983:4). The results of these studies show how the sexual difference has influenced the male text. Secondly, studying the role of women in the Gospel of Matthew through a social-scientific approach revealed the social status of women. Recently, the feminist interpretation of Jesus' studies showed that women were equal with men in the first community of Jesus (Schlüssler Fiorenza 2001:9, 11). This issue of sexual equality in Jesus' religious movement was developed and compared with the modern egalitarian theory by the feminist interpretation (Elliott 2002:75-91; cf. Dreyer 2011:1; Osiek 1997:812). Thirdly, feminist biblical studies have attempted to reveal and recover positive images of women instead of the negative images depicted in the previous androcentric exegesis (see Anderson 1983:3; Trible 1982:116). Fourthly, Matthew's Gospel does not mention the women's names among the names of Jesus' disciples. Women are just mentioned as a connection or relative of men (Wire 1991:103). However, Shin (2007:399-415) argued that the women's roles are indirectly adherent to the disciples in Matthew's Gospel. This study concluded that the women played just as important a role as the male disciples in Matthew's narrative. The women's roles were different from the roles of men in their support of Jesus' religious movement. Finally, feminist theologians have emphasised that Matthew did not put anti-Jewish pronouncements in the stories of women that included Jesus (Levine 2001:71-87). Of course, they agree when the issues of women are brought up, law and anti-Judaism is brought up as well. But Matthew's main thought implied in the women's stories is not the unclean law or anti-Judaism, but human issues. The stories of women surrounding Jesus in the Gospel of Mark are not connected with the issue of the impurity law (see Haber 2003:171-192). The main theme in the women's stories in Mark is Christology and healing miracles. The narrative of the Gospel of Matthew is deeply connected with the narrative of the Gospel of Mark. Hence, the stories of women in the Gospel of Matthew also have implied Christological themes.

The arguments above are useful to understand women's status and roles in Matthew's narrative and world. However, these studies have not considered the anti-Judaism portrayal implied in the women's stories with a Christological depiction in Matthew's narrative. This means that the women's stories relate to two matters: a Christological and an anti-Judaism depiction. The purpose of this article is to show that within Matthew's theology there was a tendency to connect the stories of the women in the Gospel of Matthew with anti-Judaic through Christological mentioning. In order to establish the hypothesis that anti-Judaism, which is depicted in a Christological way, is specifically implied in the women's stories, we will have to pay attention to the sources and features of anti-Judaism in Matthew's narrative. It is hoped that, by a thorough analysis, the kind of anti-Judaism with a Christological depiction is revealed in the stories of the women in the Gospel of Matthew through these findings. 


\section{Matthew and anti-Judaism}

Definitions of anti-Judaism have appeared in biblical, sociological, and literary studies of the Gospel of Matthew. These studies still question how Matthew's anti-Judaism is defined and what the criteria for the definition were (see Levine 1999:9-36). Despite this fact, Matthean scholars still agree that a definition of Matthew's anti-Judaism is useful (Przybylski 1986:181-200). However, it has to be considered that the Matthean community itself was still a part of the Jewish world. During the period the Gospel was composed the Matthean community defined itself as a body within Judaism. This is why the Gospel was written using the Jewish perspective. It is possible that the Matthean community shared the Jewish religion, the central place of the Torah, the identity as the people of God and the authority of the Hebrew scripture (Saldarini 1991:38-61). This would mean that the Jewish belief and practice of the law is implied in the Gospel of Matthew.

Although the Gospel of Matthew was thoroughly Jewish in belief and practice, it is noteworthy how much of Judaism's influence is actually felt in the community. The community's situation was very much that of a sectarian minority movement within a large Jewish world (Sim 1998:116). If we accept the community as a sectarian part of the parent body of Judaism, we should consider Overman's opinion (1990:8; see also White 1988:7-9) that the Jewish sect used dualistic, hostile language towards the Jewish leadership with regards to the centrality of the law.

Firstly, Matthew used dualistic language in a wide variety of antithetical terms. Sim (1998:117) mentioned that the evangelist contrasts the righteous and the doers of lawlessness (Mt 13:41-43), the righteous and the wicked (Mt 13:49), the wise and the foolish (Mt 7:24-27; 25:1-13), and the good and the wicked (Mt 5:45; 7:17-18; 12:34-35; $22: 10 ; 25: 14-30)$. These antithetical terms show us the new rigid boundaries of the Matthean community which separated them from the Jewish parent body. This means that Matthew's community comprised the righteous, good, and true Israel that has remained true to God, while those who were part of the parent body are in the wicked group.

Secondly, the sectarian section of the Matthean community was hostile towards the Jewish leadership. According to Overman (1990:6-34), at the time of Jesus, Judaism was indeed challenged by rival sects isolating themselves from each other and defining themselves as the visible remnant or core of Israel. Among such sects were the Pharisees, the Sadducees and scribes, whose leaderships were compared and competed with the leadership role of the Matthean community (cf. Blenkinsopp 1981:1-27). Matthew emphasises that the community's leadership was different from the leadership of the Pharisees, Sadducees, high priests and scribes. These groups bonded with quite disparate groups, such as the relationship between the Pharisees and Sadducees, the high priests and Pharisees, and the high priests and scribes. These groups were not individually in opposition to Jesus and the Matthean community, but were united in their opposition (Van Tilborg 1972:1-6). However, these groups' oppositions differed slightly from one another. For instance, we can see the different opinions these groups held regarding Jesus and the Matthean community in the case of resurrection of the dead. The evangelist alludes to the fact that the Pharisees and the Sadducees held different beliefs of the resurrection (Mt 22:23-33). It can be confirmed that Matthew did not have the same point view as these groups, but that he did not have a completely different view from them either (Sim 1998:118). This is why the Jewish leaders came into conflict with Jesus and the Matthean community.

The question arises as to why Matthew portrayed the Jewish leaders as different from the Matthean community and the world of Judaism. According to the past scholars, including Van Tilborg (1972:171), the community's religious foundation was very different from the foundation of the Jewish leaders. The Matthean community did not fully belong to the Jewish world (Luz 2005a:243-245). Evidence shows that the Matthean community called the people who did not convert to Christianity evil, just like they called the Jewish leaders evil , murderers, impostors, and like whitewashed tombs (Mt 23:27; 12:34, 38; 22:18). Sim's (1998:120) view is similar to Van Tilborg's opinion stated above. Matthew's theological thoughts were not coming from the real world in which he and his readers lived. This means that Matthew's theological thoughts connected with his fantasy world which was completely different from the real world. This argument is accepted by Hare's (1967:126-127) insistence that the material in the Gospel shows evidence of the conflict between the Matthean community and Jewish leader's stories and reflected the past and current situation of the Matthean community's opponents. This is the reason why the evangelist emphasises the polemic of the Matthean community between the scribes and the Pharisees. To clarify, the period of the enemy's opposition of Jesus' ministry was AD 30, whilst the period of opposition of the Matthew community was AD 80. Therefore the enemy of Jesus' ministry was the scribe group, whilst the Matthean community's enemy was the Pharisees group. These views confirmed that the Matthean community was an entirely independent and distinct group from the parent body of Judaism (Stanton 1992:96-97). The Matthean community created the new boundary for their own religious identity which was very different from the Jewish leader's teachings. Therefore, because Matthew describes the Matthean community's conflict with the Jewish leaders in the narrative of the Gospel of Matthew, it can be said that Matthew's mind headed in an anti-Judaist direction and was against the Jewish leaders.

Thirdly, the question of whether the function of the Mosaic Law in the Gospel of Matthew implies aspects of antiJudaism needs to be addressed. Traditionally, the Mosaic Law had a central position in the Gospel of Matthew and it still fulfilled an important function for the Matthean community. However, the Jewish sect of the Matthean 
community, which did not identify with formative Judaism, normally had a distinctive interpretation of the Torah from the Second Temple period. It was not clear whether the state of the Mosaic Law in the Matthean community was really independent from formative Judaism or still part of it. In fact, the interpretation of the Law was very different from the practice of each Jewish group (the Matthean community, the scribes and Pharisees). Therefore, it raises the question of whether the attitude of the Matthean community towards the Law was one of observance or abolishment. This discussion will show us that Matthew's community had anti-Judaist tendencies with regard to the practicing of the Law.

The Matthean community's observation of the Law is reflected in Matthew 5:17-19. It is very important to understand this passage, as it shows how the community thought about the observation of the Law, based on Jesus' teachings. The focus of this study is not to analyse the community's entire concept of the Law. This is why we need to understand that the purpose of Jesus' teaching was not to abolish the Law, but how Jesus' teaching was working continually in this community.

According to Walaskay (2002:417-420), Matthew 5:17-19 provides substantial evidence for the validity of the Torah in the Matthean community. This view has been confirmed by Sim (2002:775), who argues that the Matthean community was expected to obey the Law in all respects, including circumcision and other ritual requirements. However, according to Matthew 5:10-12 (21:41-45, 23:31-35), the community parted from Judaism, as it was threatened by persecution from its parent body (Shin \& Van Aarde 2005:1358). This passage shows us that Matthew's community had no further extended relationships with its parent body. Even though the Matthean community was cut off from its parent body and created a new identity as a Christian community, it still respected various aspects of Jewish tradition. Of course, the community still adhered to some aspects of the Jewish tradition (Sim 2001:274). These arguments should be considered in order to establish whether the community cut off all ties with their parent body, or whether it could still be considered as part of Judaism. That is the reason why we should discuss why Matthew mentioned Jesus' teaching of fulfilling the Law.

Matthew relates to the Law in two ways. On the one hand, Matthew still observes the 'old' Law of Moses, and on the other hand he followed the 'new' Law of Love. This perspective is evident in Jesus' teaching and interpretation of the Law (Shin \& Van Aarde 2005:1359). This means that the Gospel of Matthew holds both positive and negative perspectives in relation to the Law. Herein lies the duality of the community, as it could not deny either the validity of the Law or the basic authority and need for scribal interpretation (Shin \& Van Aarde 2005:1359). In fact, according to the Gospel of Matthew, the interpretation of the Law by a follower of Jesus or that by an ordinary Jew was quite different. The follower of Jesus recognised that Jesus' interpretation of the Law was supremely authoritative for them (Mohrlang 1984:22). Jesus' new interpretation of the Law created the situation of two different validities of the Law in certain anti-Law stories reflected in the Gospel of Matthew (Bacon 1930:168).

These teachings of Jesus in Matthew confirm that there was conflict between the Matthean community and the scribes and Pharisees. The Matthean community was separated from Judaism and stood over against Judaism (Stanton 1985:1914-1916). Nevertheless, the community retained multiple relationships with Judaism and it was not isolated. Therefore, the Matthean community was always a complex symbolic and social reality for redefining their group with shifting boundaries (Saldarini 1991:40). The result of this redefining of the community shows that it followed Jesus' teaching and the new interpretation of the Law and therefore came into conflict with the Jewish community because it followed the opposite of Jewish common symbolic elements of the Law. This conflict between Jesus and the Jewish leaders appears in Matthew's narrative and is brought about by the community's reformed program that consisted of a new interpretation of how the members of the community should live in order to replace their former understanding of the Torah and Jewish life.

Thus, it is clear that the new interpretation of the Law was deeply connected with the life of Matthew and the Jewish community in Matthew's world. This means that, according to the new interpretation of the Law, the Matthean and Jewish communities redefined their 'boundaries and expose[d] key structures and values in its social and symbolic system' (Ben-Yehuda 1985:19-20; Saldarini 1991:44). Thus, the conflict between Matthew and the Jewish community shows us that they did not accept each other's lives and lifestyle in their own interpretation of the Law. Matthew did not agree with some of the traditional teachings or the lifestyle of Jewish leaders and attacks his opponents' view of Judaism (Mt 23). Matthew's narrative testifies to the high tension within the Jewish community caused by Jesus' new interpretation of the Law. Therefore, the new interpretation of the Law and how to apply it to their lives caused conflict between the Matthean community and Jewish leaders and this is the anti-Judaism in Matthew's narrative.

To summarise, Matthew's community parted company with the Jewish parent body. The cultural background of the Matthean community consisted in part of Judaism but was not fully a part of Judaism. This indicates that Matthew used dualistic language in his sectarian perspective of the Matthean community, as they did not have the same Jewish lifestyle and were hostile against the Jewish leadership. The core of these conflicts was caused by Jesus' new interpretation of the Law, and Matthew describes this from an anti-Judaism perspective. 


\section{Women's stories implied in the aspects of anti-Judaism}

Anderson (1983:26-27) analyses verses concerning women in Matthew's Gospel, and the following verses depict 'women characters' (Mt 1:18-2:23; 8:14-17; 9:18-19, 20-22; 14:1-12; 15:21-28; 20:20; 26:6-13; 27:19; 27:55-56; 28:1-10), 'women in Jesus' teaching' (Mt 5:27-30, 31-32; 10:21, 35-39; 11:19; $13: 13 ; 15: 1-9 ; 18: 25 ; 21: 31-32 ; 24: 41 ; 1-13)$, 'female imagery' (Mt 2:18; 13:33; 21:5; 23:37; 24:8) and 'women in direct narratorial comments' $(1: 1-17 ; 2: 18 ; 14: 21 ; 15: 38 ; 27: 19)$. In fact, women's roles are not a major theme in the Gospel of Matthew. This study concerns the norms and values, the incorporated attitude towards aspects of anti-Judaism implied in women's stories. There are several passages dealing with aspects of anti-Judaism implied in women's stories above, but I will only deal with four passages. These passages include the four women in the genealogy (Mt 1:1-17), the woman with the haemorrhage (Mt 9:20-22), the Canaanite woman (Mt 15:21-28), and the women at the cross and tomb (Mt 27:55-56).

\section{Four women in the genealogy}

The genealogy of Jesus includes the names of the four Old Testament women, namely Tamar, Rahab, Ruth, and the wife of Uriah, Bathsheba. Why did Matthew include the names of four women in a patriarchal genealogy of the Messiah? These four women have been interpreted in a variety of ways (Anderson 1983:9; Hutchison 2001:152-164). Firstly, they are linked with sexuality and sin. Secondly, three of the four women are gentiles, and Bathsheba is considered a gentile because she married the gentile Uriah. The reason this genealogy is included is because of Matthew's mission to the gentiles in the Gospel. Thirdly, the four women are connected with the birth of Jesus. The women in the genealogy foreshadow and explain Mary's virgin birth and Jesus' saving his people from their sins (Hutchison 2001:153). The discussion above is traditional; the four women of the genealogy have been mainly interpreted as part of the virgin birth of the Messiah.

According to the Jewish tradition, women were not usually included in Jewish genealogies. What are the purposes and goals of Matthew for including the four women in the genealogies? The four women in the genealogy are connected to the anti-Judaic perspective through the following words: 'the levirate law', 'sinner', and 'gentile' 'sexual scandal' in the Old Testament. Firstly, the four women have showed extraordinary faith in contrast to the Jews who were greatly lacking in their 'levirate law'. According to Genesis 38, Judah married a Canaanite woman named Saua and they lived in Adullam in a foreign country. They had three sons called Er, Onan, and Shelah. Judah allowed his eldest son Er, to marry Tamar, but Er died untimely without children as a punishment from God. According to the custom law of a levirate marriage, Judah let Onan take Er's place, but God took Onan's life as well (Dt 25:5-10). Judah became afraid that his youngest son might die while following the levirate law. Then Judah sent Tamar back to her father's house. Tamar knew that she could not ensure the levirate law and present Er with a descendent. Tamar went to sit on the roadside as a prostitute and had intercourse with her father-in-law. Tamar became pregnant with Judah's baby and thus followed the levirate law.

With this example, aspects of anti-Judaism can be discussed in the story of Tamar and levirate marriage customs. The levirate marriage custom plays a vital role in providing a connection to the line of descendants of a clan, which was of major significance to Judah (Nolland 2005:74). Judah's first responsibility was to protect his family. However, he did not keep the levirate tradition and custom, but the Canaanite woman, Tamar, fulfilled it by committing adultery (Fokkelman 1996:167). This story indicates that Tamar taught and opened her father-in-law's eyes to take responsibility and secured Judah's future generation (Steinmetz 1991:45-49). According to Philo Judeaus, De virtutibus ('On the virtues' 220-222), Tamar was from Syria and grew up with the worshipping of many gods and idols. Through marriage she avoided worshipping idols and joined the pious Jewish community. By following the Jewish custom she put the custom of the levirate tradition into action. To Matthew, it seems that Tamar's behaviour of keeping the levirate tradition was better than the action of her father-in-law, Judah, who was originally a Jew (Gn 38:26). Genesis 38:26 clearly proclaims the righteousness of Tamar (cf. Philo Judaeus, Quod dues sit immutabilis, 136-137). The Hebrew term zedaqah (righteousness) is connected with Matthew's favourite word diakaiosune (righteousness), which implies aspects of anti-Judaism. Moreover, Tamar used an abnormal way to secure the family line of Judah by committing adultery with her father-in law. By looking at the fact that Matthew wrote about Tamar in a positive way, it can be assumed that Matthew's community did not see the levirate law as being significant. This serves as proof that Matthew shows aspects of anti-Judaism.

Secondly, the genealogy of Jesus including the four women shows that the four women had a primary link with a gentile ancestry and were sinners of unlawful sexual acts. Tamar was a Canaanite who committed adultery with her fatherin law (Gn 38:1-6); Ruth was a Moabite who, according to some people, used premarital seduction by 'uncovering the feet' and this may be a euphemism for uncovering the genitals (Rt 1:4); Rahab of Jericho was a prostitute (Jos 2:3); and Bathsheba, the ex-wife of Uriah the Hittite, committed adultery with king David (2 Sm 11:3). Of course, some scholars do not regard these women as representatives of the gentiles (Keener 1999:79). However, most Jewish traditions include a record of their gentile character (Gen. Rab. 50:10; 85:6; $88: 7$ cf. Johnson 1988:167-170). In fact, according to the Jewish tradition, the gentiles are an enemy of the Jewish people. Moreover, these women had broken the Jewish marital custom by having a child through an illegal method. According to the Jewish tradition, these women who committed adultery deserved public condemnation and death by stoning (cf. Freed 1987:15). However, it is true that Jewish tradition exculpates the four women in the genealogy 
of Jesus (Luz 1989:109-110). Matthew describes these women not as sinners but as heroes due to the fact that they are ancestors of Jesus who saved his people (Nolland 2005:77).

The Jewish perspective in the Gospel of Matthew does not agree with the fact that Matthew includes these unclean women in the genealogy of Jesus. The inclusion of these four women in the genealogy is an intra-Jewish debate concerning the ancestry of the Messiah (Johnson 1988:176-179). The fact that these unclean women (foreign blood and sinful women) are included in the Davidic line of the Messiah in an irregular way is supported by some scholars. However, this irregularity was opposed by the Jewish leaders in the Gospel of Matthew (Davies \& Allison 2006a:171). Hence, the purpose of Matthew using these women in the genealogy of Jesus was to put the Jewish leaders on their knees and reveal his conviction that Jesus had fulfilled the expectations of the Jewish leaders in every aspect (see Davies \& Allison 2006b:171). The discussion above shows us that there are aspects of anti-Judaism implied in the stories of the four women that Matthew describes.

\section{Haemorrhaging woman}

Recently, some Matthean scholars had a dispute about the interpretation of a new perspective concerning the 'haemorrhaging woman' story. The interpretation of the new perspective is about how the main focus is that the story of the 'haemorrhaging woman' is not deeply connected with antiJudaism and the purity laws (Levine 2001:70-87; see Haber 2003:171-192). According to Levine's interpretation (2001:87) of the haemorrhaging woman, the story does not involve antiJudaism issues, but Matthew makes a Christological point that the woman is a model of the body, the suffering and the resurrection of Christ. It is possible that the haemorrhaging woman's story implies Christological aspects. Matthew's main theology of Christology always appears in the narrative in which Matthew includes women's stories. However, Matthew's descriptions of the women's stories are not only Christological and human issues; they also include women's marginalisation and 'female problems' in the Jewish world of the1st century Palestine. However, the women's stories have compositional elements which are anti-Judaic, miraculous, and Christ-centred. This means that the haemorrhaging woman's story refers to many theological issues. The Christological issue in the haemorrhaging woman's story is more clearly exposed by an interpretation of anti-Judaism aspects. This is the reason of the need for an interpretation about an anti-Judaism aspect, the haemorrhaging woman's story.

If we accept the feminist interpretation of how the main focus of the haemorrhaging woman's story is on Christology, we need to confirm what the function of the Jewish impurity law for Christology is in this story. What Matthew offers in the story is about the new life for those who follow Jesus. Modern scholars considered the connection of the woman with the 'Jewish system': prostitutes, sinner, unclean and the state of women (see Levine 2001:71). Then the question arises: how, within the Jewish system, are the women's stories of Matthew's Gospel connected with the practice of the Law and the view of the Matthean community towards women? For example, Matthew depicted the haemorrhaging woman as marginalised in Jewish society. According to Selvidge (1990:47-70), the haemorrhaging woman was marginalised by the Jewish law on two grounds: she was a woman, and was impure. The laws concerning purity and impurity were central to the Jewish life in the 1st century Mediterranean world. Jewish communities and sects relied on their relationship with the temple in Jerusalem to decide on the interpretation of purity legislation (Haber 2003:178). Pharisees strictly observed the purity laws even outside the temple. However, some other Jewish groups and Jewish sects tried to reinterpret the purity laws for their daily lives (Haber 2003:178; Neusner 1973:65). The bleeding woman's state was regarded as an impurity in the movement of Jesus and the Matthean community.

The view of some feminist scholars is that the haemorrhaging woman is not a sign of impurity, for she stayed away from the temple for a long time (Cohen 1991:279). Matthew does not mention the bleeding woman's impurity in the text (Levine 2001:74). However, Matthew describes that the Jewish leaders were still concerned with the laws of observing women's purity in the daily life of Jews. The bleeding woman was ritually unclean because she was living with an illness in the 1st century Jewish society (Wainwright 1991:84). Moreover, Jesus was touched by the menstruating woman, and this broke the boundaries defining the Jewish law of 'clean' and 'unclean' (Hagner 1993:248; Wainwright 1991:637). This means that Jesus was not concerned with the Jewish society's purity law and that the kingdom of heaven did not respect the boundaries of purity that categorised people depending on their social status in the Jewish society (Garland 1993:107).

Here, Mathew indirectly compares the religious movement of Jesus and the religious movement of the Jewish leaders (especially the Pharisees). The more important issue is that the woman touched Jesus, and this allowed healing and salvation for the unclean woman. The bleeding woman's healing experience was just one of the life experiences with God of the Christians during those days (Luz 2001:42). In fact, Matthew expresses the view that Jesus granted salvation to the bleeding woman who was considered impure in Jewish society; yet, according to Jewish leaders, healing and salvation was never to be granted to unclean women. Hence, the story of the bleeding woman's healing and salvation becomes a Christological issue for Matthew. The Jewish leaders did not allow or give healing and salvation, but the Matthean Jesus did. Matthew's purpose of this comparison was to reveal Jesus' power of salvation for the unclean woman and to show that he was unlike the Jewish leaders (Mt 11:28), despite the fact that the Jewish leaders kept controlling the people of Israel through Jewish laws (see Levine 2001:79). Matthew's Jesus healed and saved the unclean woman because of her faith and she eventually earned a new life (see Patte 1987:132). Correctly, Matthew's Jesus did not care about or 
consider the unclean woman's state of purity according to the Jewish system. This means that Matthew's Christological expression implied aspects of anti-Judaism in the bleeding woman's story.

\section{The Canaanite woman}

The Canaanite woman's story began after the attacks of the Pharisees and scribes when Jesus withdrew once again to Tyre and Sidon (Mt 15:1-10). Traditionally, the interpretation of the story of the Canaanite woman depicts a feminist perspective of women's status, faith, and marginalisation within the Jewish system. Here, we have to consider antiJudaism with Christological aspects of the text. The Matthean Jesus' attitude towards the Canaanite woman and her daughter was not the same as those of the Jewish leaders. We will look at Matthew's Christological intention through the relationship of Jesus and the Canaanite woman. We can see what Matthew's intention with the narrative is.

Firstly, according to Matthew's vision, Tyre and Sidon are theologically significant places; these places were not significant just because they were Gentile territory, but also because the people of Tyre and Sidon were enemies of Israel (Is 23; Ezk 26-28; J13:4). According to the Old Testament, Tyre was proud and inimical to the Israelites (Josephus, Contra Apionem, I.13). In the Gospel of Mark, the Canaanite woman is identified as Syro-Phoenician because during Jesus' own day Tyre was called Syro-Phoenicia. Matthew mentions that the woman who met Jesus was a Canaanite, Israel's enemy, according to the traditional biblical identification ( $\mathrm{O}^{\prime}$ Day 2001:115). Thus, Matthew has intentionally labelled the woman a Canaanite in the narrative to show that she was an enemy of Israel and a gentile. According to the Jewish perspective, Tyre and Sidon were impure places. Jesus entered these places - this was a movement from the clean people and land to an unclean land (Derrett 1973:164). By contrast, the Jewish leader's centre was Jerusalem (cf. Mt 15:1). Here Jesus met a new interlocutor, a Canaanite woman, who sharply contrasted the Jewish leaders (Patte 1987:221). In fact, the Jewish leaders did not want go to gentile territory because it was unclean. But Jesus went to an unclean place for the demon-possessed girl. Matthew's Jesus tried to include the unclean woman who had a demon-possessed daughter in the Kingdom of God. Matthew emphasised that Jesus' religious movement accepted the unclean marginalised woman and her daughter; this intention implies aspects of anti-Judaism. The Matthean Jesus ignored the Jewish purity system. It shows that the Matthean expression of the Christological function in the Canaanite woman's story implies aspects of anti-Judaism. Moreover, the 'juxtaposition of Jesus and the Canaanite woman with the dialogue between Jesus and the Pharisees and its explanation suggests a thematic continuity, an antithetical continuity' (Patte 1987:221). The Jewish leaders complained to Jesus about why his disciples did not follow the elder's tradition of washing their hands when they ate bread (Mt 15:2). In contrast, the Canaanite woman begs Jesus for mercy on behalf of her demon-possessed daughter (Mt 15:22). Matthew explains that the Jewish leaders who observed the Law did not follow Jesus' teaching, but the gentile woman from Canaan already knew that Jesus had healing authority and power from God. This marginal woman was described by Matthew as an outsider of the Jewish system, but an insider among Jesus' religion (Keener 1999:414). Therefore, Matthew's Christological explanation in the Canaanite woman's narrative shows aspects of antiJudaism.

Secondly, when the Canaanite woman met Jesus, she cried out and begged for mercy for her daughter. The purpose of the Canaanite woman's cries was for her daughter to be healed. O'Day (2001:119) analyses the Canaanite woman's crying and believes that the cry for mercy echoes in Psalm 109:26: 'Help me O Lord my God.' In Matthew's description of the case of the Canaanite woman begging, it says, 'she worshipped him [Jesus], saying, Lord, help me' (Mt 15:25). The origin of the woman's conduct before Jesus comes from Israel's bold stance before God in the laments (O'Day 2001:119). 'The laments confront God with startling candour, placing full-bodied pleas and petitions for help and deliverance boldly before God' (O'Day 2001:119). This is originally a Jewish tradition in which the people of Israel cried to God for help (O'Day 2001:122). However, Matthew changed the term 'crying' of the Judaic laminate prayer to 'faith' in Jesus in the Canaanite woman's story. According to the Jewish system, the Canaanite woman and her demonpossessed daughter were outsiders of the Jewish society; no one listened to her. Probably some Jewish leaders reached out to the Canaanite woman hoping to make her a proselyte and to keep her in the Jewish system (cf. Josephus, Antiquitates Judaicae, 20.34-36; Contra Apionem, 2.210). But Jesus promised her God's saving presence (O'Day 2001:124). Matthew has identified that the Canaanite woman's daughter was healed by Jesus; it happened through faith. The Jewish leaders did not accept Jesus' healing power and His mention of faith (see Keener 1999:418). Matthew indicates someone on the margins of society like the Canaanite woman and her daughter who did not follow the Jewish system as a model of faith. The Matthean Jesus opened up possibilities of new life through faith; this was not allowed by the Jewish society (see Keener 1999:415). Therefore, the Gentile woman's laments and faith in Jesus are indicative of the Canaanite woman's taking the previously Jewish position of priority as the chosen people. This means that 'the Jews had priority over the Canaanites in the past, but now it was reversed through the Canaanite woman's faith' (Guardiola-Saenz 1997:75). In Jesus' ministry, the Canaanite woman's faith had more privileges than the Jewish leaders. Matthew's depiction of this priority emphasises that Jesus' saving of the gentile woman is an aspect of anti-Judaism. Jesus the Messiah comes in fulfilment of the Jewish scripture, not for the fulfilment of keeping the Jewish system made by the Jewish leader's insistence. Hence, Matthew's intention of a Christological description implies aspects of anti-Judaism in the story of the Canaanite woman's demon-possessed daughter. 


\section{The women at the cross and Jesus' tomb}

Traditionally, the women at the cross and Jesus' tomb were interpreted through redaction and source criticism (Goodenow 1886:535-547; Hodges 1966:301-309). These studies focus on analysing the narrative of the resurrection of Jesus on the cross and Jesus' tomb in the four Gospels. During recent years, studies in theology of Matthew have shown a distinct tendency to concentrate on a feminist analysis of women's state and role at the cross and tomb of Jesus' narrative (Longstaff 2001:196-204; Osiek 2001:205-220). This exegetical study has extended on that text through women's discipleship and sociological reading with anti-Judaism, but it was not much considered (Botha 2003:513-515; Meiselman 1978:73-80; Osiek 2001:214-216; Shin 2007:399-415). In this section, we will compare Matthew's designation of Christology with aspects of anti-Judaism in the women's stories of the cross and empty tomb; especially, the women's cultural behaviour at Jesus' death and resurrection implied by anti-Judaism.

In the 1st century of the Jewish society in the Mediterranean world, women's role were limited. In the Jewish society men carried out the significant tasks and spread the divine message in the patriarchal structured society, including Matthew's community (Wainwright 1991:144; Shin 2007:411). Matthew's designation of a patriarchal stance is that the Jewish leaders' main function was delivering the divine message as a power group that was male (Shin 2007:411). Botha (2003:513) said that Matthew's depiction of the women at the cross and the tomb was more positive than that of Mark, even though Matthew did not depict these women as disciples. However, this story reveals to us that the women's role at the cross and the tomb is significant. Even if these women were not actually disciples of Jesus, their behaviour was better than that of the male disciples (Shin 2007:410).

Here we will look at the behaviour of the Jewish leaders and the women at the cross and the tomb. Jesus' death and resurrection are core theological issues in Matthew's community. However, Matthew depicted the male disciples' role as not significant in Jesus' cross and tomb stories. Thus, we will compare the different attitudes of the Jewish leaders and the women at the cross and tomb towards God's will of redemption through Jesus as a divine message of his death and resurrection. As we know, the Jewish leaders' role was to deliver the divine message, but their behaviour was not that of messengers of the divine message according to the Matthean depiction (Mt 27:12, 20,41). The Jewish leaders disturbed God's will of Jesus' death and resurrection. They did not accept Jesus' death as God's action and will of salvation. By contrast, the women at the cross and tomb were those who stayed close to the crucified Jesus and visited his tomb.

The women were just watching in silence from a distance. This means that the women supported Jesus during his ministry. They supported Jesus' ministry which was from Galilee to
Jerusalem, indirectly as adherent disciples (Luz 2005b:574). 'The women have significant roles, but are not brought to light in terms of the dynamics of the patriarchal society in Matthew's narrative' (Shin 2007:411). The Jewish system did not much allow women's activity, but Matthew depicts the women's role as more significant than the roles of the male disciples and the Jewish leaders through the narrative of the women at the cross and tomb. Thus, the women's significant role implied aspects of anti-Judaism.

Next, we will consider how Matthew depicts the women's witness of Jesus' empty tomb through his Christian perspective. The women's witness of Jesus' resurrection is also a big debating issue in Jesus' empty tomb narrative. Matthew mentions, 'in the end of the Sabbath, the first day of the week' (Mt 28:1) - this reveals that Matthew's depiction follows a common Jewish designed style (Luz 2005b:594). It shows that Matthew's community still followed the Jewish system and shared the Jewish social background. In contrast, Matthew does not depict the women in the story of Jesus' empty tomb in a common Jewish fashion. We will examine how Matthew designates the women in Jesus' death and resurrection. The intention of Matthew's depiction is to show that the resurrected Jesus is God and that he actually acted by coming out of the tomb (Luz 2005b:595). The women saw the empty tomb of Jesus, but the Jewish leaders strategically denied Jesus' resurrection.

In fact, women in Jewish society are perceived as having closer contact with death, and this connection made the Jewish system unclean and contaminant (Osiek 2001:214). Moreover, Jewish leaders requested and obtained soldiers to guard the tomb of Jesus (Mt 27:64-66). Although the women did not touch Jesus' dead body, they were already impure for visiting the unclean place of the tomb. It shows us that the Jewish leaders did not expect Jesus' resurrection and considered Jesus' tomb an unclean place. However, the women's faith made them visit Jesus' tomb, which was considered unclean. The visit to Jesus' empty tomb implies aspects of anti-Judaism.

Matthew's depiction of the women's testimony of Jesus' resurrection also reveals aspects of anti-Judaism. According to Jewish law, women's public witnesses had to be checked to distinguish whether they had merit or not. The women's testimonies emphasise Jesus' resurrection, but the guards' testimony says that the disciples of Jesus stole him while he slept (Mt 28:13). This means that 'Matthew lays these two reports, the true and the false, side by side, forcing his audience to declare their choice' (Keener 1999:699).

The role of women in funeral services during the 1st century of Jewish society was to prepare a body for burial, and the man's role was to accompany the body into the tomb (Osiek 2001:214). Instead, the women visited the tomb of Jesus in Matthew's narrative. Moreover, the women's testimonies were not accepted by the official forum in Jewish society. Women's testimonies were valued and drawn upon in the 
sphere of private affairs (Osiek 2001:216). This means that women were not allowed to give testimonies in ancient Judaia, because women were incompetent witnesses (Davies \& Allison 2006b:661). This is why, in the official testimony of 1 Corinthians 15 , there is an absence of the appearances and depictions of women, because they were not allowed to serve as a public witness. Matthew knew the Jewish system, which included the Jewish custom that women were incompetent witnesses. If that was the case, why did Matthew cast women's witnesses at Jesus' resurrection? The women arrived at the tomb of Jesus and found that the tomb was guarded by representatives of the Jewish leaders. By contrast, the women were representatives of the Christian witness of the Matthean community. The women became a model for the disciples of the Matthean community (Keener 1999:699). Hence, Matthew's depiction of women witnesses implies aspects of anti-Judaism in Jesus' death and resurrection at the empty tomb.

\section{Conclusion}

In this study we have attempted to demonstrate that the women's stories implied aspects of anti-Judaism within Matthew's depiction of Christology, which we call Matthew's theology. The Gospel of Matthew shows a positive perspective on the Jewish tradition and this is why we call it the Jewish Gospel. Matthew's community opposed the Jewish system and Jewish leaders and parted with their parent body, Judaism. This kind of anti-Judaism widely exists in Matthew's narrative.

I have discussed these aspects of anti-Judaism that appear in the women's stories of Matthew's Christology. Four women in the genealogy reveal aspects of anti-Judaism with a Christological depiction. The genealogy of Jesus shows the virgin's birth of Jesus who is the Messiah. Matthew's description of the baby Jesus' birth not only intends to show that he is the Messiah, but also implies anti-Judaism sentiments. In the case of the haemorrhaging woman's story, Matthew's depiction of this story demonstrates the Christological authority of Jesus' healing power. The Matthean Jesus touches the unclean woman and this clearly reveals an anti-Judaism aspect. Jesus' healing of the unclean bleeding woman breaks the boundaries of the Jewish system, which was concerned with the Jewish Law. The story of the Canaanite woman also shows Jesus' power of healing and saving the demon-possessed girl with Christological power. This story does not only involve the unclean woman's faith within a Christological depiction, but also has the intention of Matthew to try to effect practicing anti-Judaism as a mission for Gentiles. The women at the cross and Jesus' tomb are indications of about Jesus' death and resurrection as Christological depiction by Matthew. It describes the conflict between Matthew's Christian witnesses and the witness of the guard who sides with the Jewish leaders. This is another anti-Judaism aspect with Christological description. Therefore, the women's stories imply aspects of anti-Judaism with Christological depictions by Matthew's theological tendency.

\section{Acknowledgements Competing interests}

The author declares that he has no financial or personal relationship(s) that may have inappropriately influenced him in writing this article.

\section{References}

Abel, E., 1981, 'Editor's introduction', Critical Inquiry 8, 179-84. http://dx.doi. org/10.1086/448149

Anderson, J.C., 1983, 'Matthew: Gender and reading', Semeia 28, 3-27.

Bacon, B.W., 1930, Studies in Matthew, Constable, London.

Balch, D.L., 1991, 'The Greek political topos Пepr vó $\mu \omega v$ and Matthew 5:17, 19 and 16:19', in D.L. Balch (ed.), Social history of the Matthean community: Crossdisciplinary approaches, pp. 68-86, Fortress, Minneapolis.

Ben-Yehuda, N., 1985, Deviance and moral boundaries: Witchcraft, the ccult, science fiction, deviant sciences and scientists, University of Chicago Press, Chicago.

Blenkinsopp, J., 1981, 'Interpretation and the tendency to sectarianism: an aspect of the Second Temple History', in E.P. Sanders (ed.), Jewish and Christian SelfDefinition, vol. 2, pp. 1-27, SCM, London.

Botha, P.J.J., 2003, 'The Gospel of Matthew and women', In die Skriflig/In Luce Verbi 37(3), 505-532. http://dx.doi.org/10.4102/ids.v37i3.480

Cohen, D, 1991, Law, sexuality, and society: The enforcement of morals in classical Athens, Cambridge University Press, Cambridge.

Davies, W.D. \& Allison, D.C., 2006a, A critical and exegetical commentary on the Gospel according to Saint Matthew 1-7, T \& T Clark, Edinburgh.

Davies, W.D. \& Allison, D.C., 2006b, A critical and exegetical commentary on the Gospel according to Saint Matthew 19-28, T \& T Clark, Edinburgh.

Derrett, J.D.M., 1973, 'Law in the New Testament: The Syro-Phoenician woman and the centurion of Capernaum', Novum Testamentum 15(3), 161-186. http://dx.doi. org/10.2307/1560339http://dx.doi.org/10.1163/156853673X00015

Dreyer, Y., 2011, 'Gender critique on the narrator's androcentric point of view of women in Matthew's Gospel', HTS Teologiese Studies/Theolocial Studies 67(2), 1-5. http://dx.doi.org/10.4102/hts.v67i1.898

Elliot, J.H., 2002, 'Jesus was not an egalitarian: A critique of an anachronistic and idealist theory', Biblical Theology Bulletin 32(2), 75-91. http://dx.doi. org/10.1177/014610790203200206

Fokkelman, J.P., 1996, 'Genesis 37 and 38 at the interface of structural analysis and hermeneutics', in L.J. De Regt (ed.), Literary structure and rhetorical strategies in the Hebrew Bible, pp. 152-187, Eisenbrauns, Winona Lake.

Freed, E.D., 1987, 'The women in Matthew's genealogy', Journal for the Study of the New Testament 29, 3-19.

Garland, D., 1993, Reading Matthew: A literary and theological commentary on the first Gospel, Crossroad, New York.

Goodenow, S.B., 1886, 'Women at the tomb: A harmony of the resurrection account', BHC 6(35), 535-547.

Guardiola-Saenz, L.A., 1997, 'Borderless woman and borderless texts: A cultural reading of Matthew 15:21-18', Semeia 78, 69-81.

Haber, S., 2003, 'A woman's touch: Feminist encounters with the haemorrhaging woman in Mark 5:24-34', Journal for the Study of the New Testament 26(2), 171-192.

Hagner, D., 1993, Matthew 1-13, Word Books, Dallas. (WCC 33).

Hare, D.R.A., 1967, The theme of Jewish persecution of Christians in the Gospel according to St Matthew. Cambridge University Press, Cambridge. http://dx.doi. org/10.1017/CBO9780511659584

Hodges, Z.C., 1966, 'The women and the empty omb', Bibliotheca Sacra 123, 301-309.

Hutchison, J.C., 2001, 'Women, gentiles, and the messianic mission in Matthew's genealogy', Bibliotheca Sacra 158(2), 152-164.

Johnson, M.D., 1988, The purpose of Biblical genealogies: With special reference to the setting of the genealogies of Jesus, Cambridge University Press, Cambridge.

Josephus, Flavius, [1 CE] [1892] 1955, 'Antiquitates Judaicae', in B. Niese (ed.), Flavii Josephi opera, vol. 2, pp. 3-392, Weidmann Verlag, Berlin

Josephus, Flavius, [1 CE] [1989] 1955, 'Contra Apionem', in B. Niese (ed.), Flavii Josephi opera, vol. 5, pp. 3-99, Weidmann Verlag, Berlin.

Keener, C.S., 1999, A Commentary on the Gospel of Matthew, Eerdmans, Grand Rapids.

Levine, A-J., 1999, 'Anti-Judaism and the Gospel of Matthew' in W.R. Farmer (ed.), Anti-Judaism and the Gospel, pp. 9-36, Trinity Press International, Harrisburg.

Levine, A-J., 2001, 'Discharging responsibility: Matthean Jesus, biblical law, and hemorrhaging woman', in A-J. Levine \& M. Blickenstaff (eds.), A feminist companion to Matthew, pp. 70-87, Sheffield Academic Press, Sheffield.

Longstaff, T.R.W., 2001, 'What are those women doing at the tomb of Jesus? Perspectives on Matthew 28:1', in A-J. Levine \& M. Blickenstaff (eds.), A feminist companion to Matthew, pp. 196-204, Sheffield Academic Press, Sheffield. 
Luz, U., 1989, Matthew 1-7: A commentary, transl. J. Bowden, SCM Press, London. Luz, U., 2001, Matthew 8-20, transl. J.E. Crouch, Fortress, Minneapolis. (HCHCB)

Luz, U., 2005a, Studies in Matthew, transl. R. Selle, William B. Eerdmans Publishing Company, Grand Rapids.

Luz, U., 2005b, Matthew 21-28, transl. J.E. Crouch, Fortress, Minneapolis. (HCHCB).

Meiselman, M., 1978, Jewish woman in Jewish Law, Ktav, New York.

Mohrlang, R., 1984, Matthew and Paul: A comparison of ehical perspective, Cambridge University Press, Cambridge. http://dx.doi.org/10.1017/CBO9780511520426

Neusner, J., 1973, From politics to piety: The emergence of Pharisaic Judaism, PrenticeHall, Englewood Cliffs.

Nolland, J., 2005, The Gospel of Matthew: A commentary on the Greek text, William B. Eerdmans Publishing Company, Grand Rapids.

O'Day, G.R., 2001, 'Surprised by faith', in A-J Levine \& M. Blickenstaff (ed.), A feminis companion to Matthew, pp. 114-125, Sheffield Academic Press, Sheffield.

Osiek, C., 1997, 'Jesus and cultural values: Family life as an example', HTS Teologiese Studies/Theological Studies 53(3), 800-814. http://dx.doi.org/10.4102/hts. v53i3.1701

Osiek, C., 2001, 'The women at the tomb: What are they doing there?', in A-J. Levine \& M. Blickenstaff (eds.), A feminist companion to Matthew, pp. 205-220, Sheffield Academic Press, Sheffield.

Overman, J.A., 1990, Matthew's Gospel and formative Judaism: The social world of The Matthean community, Fortress, Minneapolis.

Patte, D., 1987, The Gospel according to Matthew: A structural commentary on Matthew's faith, Fortress, Philadelphia.

Philo Judaeus [1 BCE -1 CE] [1896] 1962a, 'De virtitubis' ('On the virtues'), 220-222, in L. Cohn \& P. Wendland (ed.), Philonis opera quae superunt, pp 266-335, De Gruyter, Berlin.

Philo Judaeus, [1 BCE - 1 CE] [1896] 1962b, 'Quod dues sit immutabilis', 136-137, in L. Cohn \& P. Wendland (ed.), Philonis opera quae superunt, pp. 56-94, De Gruyter, Berlin.

Przybylski, B., 1986, 'The setting of Matthean anti-community', in P. Richardson \& D. Granskou (eds.), Anti-Judaism in early Christianity, vol. 1, Paul and the Gospels, Granskou (eds.), Anti-Judaism in early Christianity, vol.
pp. 186-200, Wilfrid Laurier University Press, Waterloo.

Saldarini, A.J., 1991, 'The Gospel of Matthew and Jewish-Christian conflict', in D.L. Balch (ed.), Social history of the Matthean community: Cross-disciplinary approaches, pp. 38-61, Fortress, Minneapolis.
Schlüssler, F., 2001, Wisdom way: Introducing feminist biblical interpretation, Orbis Books, Maryknoll.

Selvidge, M.J., 1990, Woman, cult and miracle recital: A redactional critical investigation on Mark 5.24-34, Associated University Press, London.

Shin, I. \& Van Aarde, A.G., 2005, 'Matthew's and Paul's inclusive tendencies: A comparison', HTS Teologiese Studies/Theological Studies 61(4), 1353-1372. http://dx.doi.org/10.4102/hts.v61i4.488

Shin, I., 2007, 'Matthew's designation of the role of women as indirectly adherent disciples', Neotestamentica 42(2), 399-415.

Sim, D.C., 1998, The Gospel of Matthew and Christian Judaism: The history and social setting of the Matthean community, T \& T Clark, Edinburgh.

Sim, D.C., 2001, 'The social setting of the Matthean community: New paths for an old journey', HTS Teologiese Studies/Theological Studies 57, 268-280.

Sim, D.C., 2002, 'Matthew and Anti-Paulinism: A neglected feature of Matthean studies', HTS Teologiese Studies/Theological Studies 58(2), 767-783. http:// dx.doi.org/10.4102/hts.v58i2.557

Stanton, G.N., 1985, 'The origin and purpose of Matthew's Gospel: Matthean scholarship from 1945 to 1980 ', in H. Temporini, \& W. Hasse (eds.), Aufstieg und Niedergang der römischen Welt II.25.3, pp. 1890-1951, De Gruyter, Berlin.

Stanton, G.N., 1992, A gospel for a new people: Studies in Matthew, T \& T Clark, Edinburgh.

Steinmetz, D., 1991, From father to son: Kinship, conflict and continuity in Genesis, LCBI, Louisville: John Knox, Louisville.

Trible, P., 1982, 'Feminist hermeneutics and Biblical studies', Christian Century 116 3-10.

Van Tilborg, S., 1972, The Jewish leaders in Matthew, Brill, Leiden.

Walaskay, R.W., 2002, 'Matthew 5:17-19', Interpretation 25(1), 417-420. http:// dx.doi.org/10.1177/002096430005600409

Wainwright, E., 1991, Toward a feminist critical reading of the Gospel of according to Matthew, De Gruyter, Berlin. http://dx.doi.org/10.1515/9783110877106

White, L.M., 1988, 'Shifting sectarian boundaries in early Christianity', Bulletin of the John Rylands Library 70(3), 7-24.

Wire, A.C., 1991, 'Gender roles in a scribal community', in D.L. Balch (ed.), Social History of the Matthean community: Cross-disciplinary approaches, pp. 87-111, Fortress, Minneapolis. 